\title{
The baroclinic transport of the Antarctic Circumpolar Current south of Africa
}

\section{Jean-François Legeais ${ }^{1 *}$, Sabrina Speich ${ }^{1}$, Michel Arhan ${ }^{1}$, Isabelle Ansorge ${ }^{2}$, Eberhard Fahrbach ${ }^{3}$, Silvia Garzoli ${ }^{4}$, Alexander Klepikov}

\author{
${ }^{1}$ Laboratoire de Physique des Océans, CNRS/IFREMER/UBO, Brest, France \\ ${ }^{2}$ Oceanography Department, University of Cape town, South Africa \\ ${ }^{3}$ Alfred Wegener Institute for Polar and Marine Research, Bremerhaven, Germany \\ ${ }^{4}$ Physical Oceanography Division, NOAA-AOML, Miami, USA \\ ${ }^{5}$ Arctic and Antarctic Research Institute, St-Petersburg, Russia \\ *: Corresponding author : Jean.Francois.Legeais@ifremer.fr
}

\begin{abstract}
Five hydrographic transects at nominal longitudes $0^{\circ} \mathrm{E}$ and $30^{\circ} \mathrm{E}$, and fourteen expendable bathythermograph (XBT) sections near the former longitude are used to study the baroclinic transport of the Antarctic Circumpolar Current (ACC) between Africa and Antarctica. The bottom-referenced geostrophic transport between the Subtropical Front and the ACC Southern Boundary is $147 \pm 10 \mathrm{~Sv}$. Estimating the transport from the XBTs using a technique previously employed south of Australia proves delicate because of an irregular bathymetry and water mass variations. It nevertheless confirms ACC transports around $150 \mathrm{~Sv}$. Gathering these and other estimates from the Atlantic sector suggests that, while North Atlantic Deep Water is injected in the current west of $35^{\circ} \mathrm{W}$, a partially compensating loss of Deep Circumpolar Water occurs east of this longitude. Another transport increase from $0^{\circ} \mathrm{E}$ to $30^{\circ} \mathrm{E}$ might reflect southward transfer across the Subtropical Front south of the Agulhas retroflection.
\end{abstract}




\title{
The baroclinic transport of the Antarctic Circumpolar Current south of Africa
}

Jean-François Legeais ${ }^{1}$, Sabrina Speich ${ }^{1}$, Michel Arhan ${ }^{1}$, Isabelle Ansorge ${ }^{2}$, Eberhard Fahrbach $^{3}$, Silvia Garzoli ${ }^{4}$, Alexander Klepikov ${ }^{5}$

${ }^{1}$ Laboratoire de Physique des Océans, CNRS/IFREMER/UBO, Brest, France

${ }^{2}$ Oceanography Department, University of Cape town, South Africa

${ }^{3}$ Alfred Wegener Institute for Polar and Marine Research, Bremerhaven, Germany

${ }^{4}$ Physical Oceanography Division, NOAA-AOML, Miami, USA

${ }^{5}$ Arctic and Antarctic Research Institute, St-Petersburg, Russia

\begin{abstract}
:
Five hydrographic transects at nominal longitudes $0^{\circ} \mathrm{E}$ and $30^{\circ} \mathrm{E}$, and fourteen expendable bathythermograph (XBT) sections near the former longitude are used to study the baroclinic transport of the Antarctic Circumpolar Current (ACC) between Africa and Antarctica. The bottom-referenced geostrophic transport between the Subtropical Front and the ACC Southern Boundary is $147 \pm 10 \mathrm{~Sv}$. Estimating the transport from the XBTs using a technique previously employed south of Australia proves delicate because of an irregular bathymetry and water mass variations. It nevertheless confirms ACC transports around $150 \mathrm{~Sv}$. Gathering these and other estimates from the Atlantic sector suggests that, while North Atlantic Deep Water is injected in the current west of $35^{\circ} \mathrm{W}$, a partially compensating loss of Deep Circumpolar Water occurs east of this longitude. Another transport increase from $0^{\circ} \mathrm{E}$ to $30^{\circ} \mathrm{E}$ might reflect southward transfer across the Subtropical Front south of the Agulhas retroflection.
\end{abstract}

\section{Introduction}

Improved descriptions of the Antarctic Circumpolar Current (ACC) and estimations of its intensity are precious information for a better understanding of this current dynamics and role in the thermohaline circulation. Here we examine the ACC baroclinic transport in the region south of Africa, the least investigated of the three passages to the south of the southern hemisphere continents. We focus on the transport of the ACC proper, i.e. on the domain located between the Subtropical Front (STF) and the current Southern Boundary (SBdy; Orsi et al., 1995), and on the contributions of the ACC fronts to the transport. We use five CTD (Conductivity-Temperature-Depth) transects at the two nominal longitudes $0^{\circ} \mathrm{E}$ and $30^{\circ} \mathrm{E}$, and fourteen XBT (Expendable Bathythermograph) lines close to the western site. The latter are analysed for transport computations through a proxy technique previously employed by Rintoul et al. (2002) and Sokolov et al. (2004). After determining a relation between 
temperature and potential energy anomaly required by this method, we present the ACC transports estimated from the CTD data and the XBTs. We discuss elements of the frontal current structure and compare the ACC transports with other estimates in the Atlantic sector.

\section{The $\chi$-T relationship.}

The poleward shoaling of isopycnals and isotherms in the ACC results in a monotonously increasing relation between the temperature at a given depth and the potential energy anomaly

$$
\chi(p 0)=\frac{1}{g} \int_{0}^{p 0} p \delta d p
$$

where $\delta$ is the specific volume anomaly, $g$ the acceleration of gravity, $\mathrm{p}$ the pressure, and $\mathrm{p}_{0}$, $\mathrm{z}_{0}$ and $\rho_{0}$ the reference pressure, depth, and density, respectively. The zonal and meridional geostrophic volume transports per unit width, above and relative to $\mathrm{p}_{0}\left(\mathrm{z}_{0}\right)$, are:

$$
U(p 0)=\int_{z 0}^{0} u d z=-\frac{1 \partial \chi(p 0)}{\rho 0 f \quad \partial y}, \quad V(p 0)=\int_{z 0}^{0} v d z=\frac{1 \partial \chi(p 0)}{\rho 0 f \quad \partial x}
$$

Following Rintoul et al. (2002), we compute the potential energy anomaly $\chi_{2500}$ integrated between the surface and $2500 \mathrm{dbar}$, and we examine its relation to the temperature averaged between 600 and $700 \mathrm{dbar}\left(\mathrm{T}_{650}\right)$ that can be deduced from XBT profiles. The $\chi_{2500^{-}}$ $\mathrm{T}_{650}$ relation is established from a set of five CTD transects (Table 1, Fig. 1). One of the transects (I6s) was interrupted northward at $44^{\circ} \mathrm{S}$, about two degrees south of the STF, and

\begin{tabular}{|c|c|c|c|c|c|}
\hline Section & AJAX & A12 & A21 & I6 & I6s \\
\hline Date & Jan. 1984 & May- Aug. 1992 & Jan.-Mar.1990 & Feb.-Mar.1996 & Jan.-Mar. 1993 \\
\hline Ship & RV Knorr & R/V Polarstern & R/V Meteor & N/O Marion Dufresne & N/O Marion Dufresne \\
\hline $\begin{array}{l}\text { Institution } \\
\text { Chief scientist }\end{array}$ & $\begin{array}{l}\text { Texas A\&M Univ. } \\
\text { T. Whitworth }\end{array}$ & $\begin{array}{l}\text { A.W.I. } \\
\text { P. Lemke }\end{array}$ & $\begin{array}{l}\text { Univ. Bremen } \\
\text { W. Roether }\end{array}$ & $\begin{array}{l}\text { LBCM, Paris } \\
\text { A. Poisson }\end{array}$ & $\begin{array}{l}\text { LBCM, Paris } \\
\text { A. Poisson }\end{array}$ \\
\hline Source & Whitworth and Nowlin (1987) & \begin{tabular}{|l|} 
Lemke (1994) \\
\end{tabular} & Roether et al. (1990) & Park et al. (2001) & http://whpo.ucsd.edu \\
\hline
\end{tabular}
therefore does not close the ACC to allow transport estimates.

Figure 2 shows the relation between $\chi_{2500}$ and $\mathrm{T}_{650}$ obtained from all hydrographic stations and the adjusted $8^{\text {th }}$ degree polynomial. Separate estimates for the western and eastern sites are also displayed. The relationship shows low dispersion for temperatures up to about $3.5^{\circ} \mathrm{C}$, where it diverges in two branches approximately corresponding to the two sampled longitudes. Salinity sections and temperature-salinity plots revealed that this divergence 
corresponds to the presence of two different varieties of Antarctic Intermediate Water (AAIW), one of lower salinities $\left(\mathrm{S}_{\min }<34.3\right)$ recently subducted and present at the ACC stations of the Atlantic sector, and a more saline Indian Ocean variety brought to the region by the Agulhas Current. The latter influences the northern part of the ACC south of the Agulhas retroflection (Read and Pollard, 1993). Owing to a transfer of part of this Indian Ocean AAIW to the Atlantic (Gordon et al., 1992), some of it may occasionally penetrate the northern ACC domain farther west. This apparently occurred at three stations of A12 whose $\chi_{2500}-\mathrm{T}_{650}$ points are on the Indian Ocean branch of the curve (Fig.2).

\section{ACC transport estimates from CTD data}

South of Africa, the ACC flows between the South Atlantic and South Indian subtropical domains in the north, and the eastern part of the Weddell gyre in the south. Likely constrains by these adjacent circulations, and a possible effect of the underlying topography, result in a southward shift of the ACC, from about $38^{\circ} \mathrm{S}-56^{\circ} \mathrm{S}$ at $0^{\circ} \mathrm{E}$ to $42^{\circ} \mathrm{S}-60^{\circ} \mathrm{S}$ at $30^{\circ} \mathrm{E}$ (Fig.1). In order to locate the ACC boundaries (and fronts) on the CTD and XBT sections, we used temperature criteria proposed by Orsi et al. (1995), that we list in table 2:

\begin{tabular}{|c|c|}
\hline STF & $10^{\circ} \mathrm{C}<\theta_{100 \mathrm{~m}}<12^{\circ} \mathrm{C}$ \\
\hline SAF & $\theta>4-5^{\circ} \mathrm{C}$ at $400 \mathrm{~m}$, farther north \\
\hline PF & $\theta<2{ }^{\circ} \mathrm{C}$ along the $\theta_{\min }$ at $\mathrm{z}<200 \mathrm{~m}$, farther south \\
\hline SACCF & $\theta>1.8^{\circ} \mathrm{C}$ along $\theta_{\max }$ at $\mathrm{z}>500 \mathrm{~m}$, farther north \\
& $\theta<0^{\circ} \mathrm{C}$ along $\theta_{\min }$ at $\mathrm{z}<150 \mathrm{~m}$, farther south \\
\hline SBdy & Southern limit of vertical maximum of $\theta>1.5^{\circ} \mathrm{C},(\sim 200 \mathrm{~m})$ \\
\hline
\end{tabular}

Table 2: Temperature criteria used to detect the ACC fronts, reproduced (or adapted for the SBdy) from Orsi et al. (1995). STF, Subtropical Front; SAF, Subantarctic Front; PF, Polar Front; SACCF, Southern Antarctic Circumpolar Current Front; SBdy, Southern Boundary.

The CTD-inferred ACC limits (Table 3) were all found within 2 degrees of the estimates of Orsi et al. (1995) (Fig.1). The width of the ACC shows some variability at $0^{\circ} \mathrm{E}$ (the average width is $14.8^{\circ}$, with a range between 13 to $15.7^{\circ}$ ). A widening of about 3 degrees predicted by the patterns of Orsi et al. (1995) between this longitude and $30^{\circ} \mathrm{E}$ is confirmed. The ACC transports (above and relative to $2500 \mathrm{dbar}$, and above and relative to the bottom) also given in Table 3 are averages of low- and high-side estimates provided by the stations bounding the fronts (CTD transport uncertainties in this Table are half the differences of these high and low estimates). Averaging the four available CTD estimates, the ACC baroclinic transports relative to $2500 \mathrm{dbar}$ and the bottom are $\operatorname{Tr}_{2500}=87.5 \pm 3 \mathrm{~Sv}$ and $\operatorname{Tr}_{\text {bottom }}=146.9 \pm 10 \mathrm{~Sv}$ (1 
$\mathrm{Sv}=10^{6} \mathrm{~m}^{3} \mathrm{~s}^{-1}$ ), respectively (here the uncertainty is the standard deviation computed from the five estimates). $T$ he $\operatorname{Tr}_{2500} / \operatorname{Tr}_{\text {bottom }}$ ratio, a useful parameter to estimate full depth transports from XBT-inferred $\operatorname{Tr}_{2500}$ values, is $0.61 \pm 0.05$ at the western site where XBT data are available. Note that this ratio is 0.68 for A21 because of an average shallower topography along the eastward-shifted track of this line.

\begin{tabular}{|c|c|c|c|c|c|c|}
\hline & AJAX & A12 & A21 & XBTs & I6 & I6s \\
\hline STF $\left({ }^{\circ} \mathrm{S}\right)$ & $39.5(1)$ & $39.8(0.5)$ & $41.7(0.9)$ & $41.8 \pm 1.1$ & $42.3(0.7)$ & - \\
\hline SBdy $\left({ }^{\circ} \mathrm{S}\right)$ & $55.2(1.2)$ & $55.5(2)$ & $54.7(0.8)$ & $55.9 \pm 1.2$ & $61.0(0.3)$ & $60.5(1.4)$ \\
\hline $\begin{array}{c}\text { ACC width } \\
\left({ }^{\circ} \text { latitude }\right)\end{array}$ & 15.7 & 15.7 & 13.0 & 14.1 & 18.7 & - \\
\hline $\operatorname{Tr}_{2500}(\mathrm{~Sv})$ & $88.6 \pm 8$ & $87.5 \pm 3$ & $90.6 \pm 4$ & $97.5 \pm 5$ & $83.3 \pm 1$ & - \\
\hline $\operatorname{Tr}_{\text {bottom }}(\mathrm{Sv})$ & $155.9 \pm 17$ & $144.9 \pm 10$ & $132.9 \pm 3$ & - & $153.7 \pm 7$ & - \\
\hline
\end{tabular}

Table 3: ACC latitudinal limits and widths, and ACC baroclinic transports above and relative to 2500 dbar and the bottom $\left(\operatorname{Tr}_{2500}, \operatorname{Tr}_{\text {bottom }}\right)$, estimated from the CTD and XBT transects. Frontal widths are in parentheses in the two first lines. Transport CTD estimations use geostrophy, XBT estimations use the $\chi_{2500}-\mathrm{T}_{650}$ relationship.

\section{XBT-inferred estimates of the ACC transport}

The ACC transport uncertainty related to the $\chi_{2500}-\mathrm{T}_{650}$ relationship was estimated by using the empirical relations with the $\mathrm{T}_{650}$ values from the hydrographic lines, and comparing the ensuing transports with those computed through geostrophy. On average, the $\operatorname{Tr}_{2500}$ values inferred from the $\chi_{2500}-\mathrm{T}_{650}$ relation exceeded the geostrophic estimates by $1.3 \mathrm{~Sv}$, with individual differences ranging from $-3.4 \mathrm{~Sv}$ for A12 to $4.1 \mathrm{~Sv}$ for I6s, and no significant difference between the western and eastern sites. Although the slight overestimation by XBT data is within the transport error bars, we note that, because of two isolated stations shallower than 2500 dbar in A12 (one at 1700 dbar), the XBT-inferred transports had to be replaced by the geostrophic estimates for the comparison to be meaningful. Ignoring the shallow stations increases the overestimation to $5.4 \mathrm{~Sv}$, an indication of possible bias of the XBT estimates in this region of numerous seamounts. The occasional presence of Indian Ocean AAIW in the northern ACC, as observed in A12, is another potential cause of positive bias when using the western site $\chi_{2500}-T_{650}$ relation. Such effect, comparable in magnitude to the bathymetryinduced bias, is expected when anomalous water is present right at the northern end of the ACC.

The proxy method using the $\chi_{2500}-\mathrm{T}_{650}$ relation at $0^{\circ} \mathrm{E}$ was applied to $14 \mathrm{XBT}$ sections (Fig.3) located slightly to the east of the CTD lines of the western site (Fig.1). The XBT- 
inferred ACC transports relative to 2500 dbar are $97.5 \pm 5.5 \mathrm{~Sv}$, that is, $8.6 \mathrm{~Sv}$ (or $\sim 10 \%$ ) higher than the 88.9 Sv average from the three Atlantic CTD lines (Table 3). The sign and magnitude of this difference both suggest that it might be due to the bathymetric and water mass effects discussed above. Roughly assuming a $5 \mathrm{~Sv}-10 \mathrm{~Sv}$ overestimation, and applying the $61 \% \mathrm{Tr}_{2500} / \mathrm{Tr}_{\text {bottom }}$ ratio, the XBT-inferred ACC transport at $0^{\circ} \mathrm{E}$ ranges between $143 \mathrm{~Sv}$ and $151 \mathrm{~Sv}$.

\section{The ACC fronts south of Africa:}

Table 2 gives definitions for the Subantarctic Front (SAF), the Polar Front (PF), and the Southern ACC Front (SACCF). We located these fronts and, in order to estimate their associated transports, we determined their widths visually using the transport meridional distributions.

The XBT-inferred front positions (Fig. 3) generally match the traces of Orsi et al. (1995), the only significant discrepancy being the track of the SAF past the Meteor Rise near $47^{\circ} \mathrm{S}-7^{\circ} \mathrm{E}$, which is observed north of the bathymetry in all sections (including the CTD ones). A topographic guidance of the SBdy by the America-Antarctic ridge and the Southwest Indian ridge that limit the Weddell Basin northward is confirmed.

The baroclinic transports of each front and their contributions to the ACC transport are reported in Table 4. The XBT-inferred frontal contributions are comparable to those obtained from the CTD sections at $0^{\circ} \mathrm{E}$, with the exception of the STF one $(10 \%$ versus $4 \%)$. At $30^{\circ} \mathrm{E}$, the exceeding of the net transport by the added frontal contributions as defined here $(136 \%$ for $\mathrm{T}_{\text {bottom }}$ ) betrays flow reversals visible on the cumulative transport curves at this longitude (Fig.4b). This situation hinders a definition of the frontal latitudinal bands at $30^{\circ} \mathrm{E}$ and suggests considering the individual front transport estimates at $30^{\circ} \mathrm{E}$ cautiously. The $0^{\circ} \mathrm{E}$ transport curves are more regular (Fig.4a), with only one reversal on A12 south of the STF, at the location where more saline AAIW was observed.

Table 4 further indicates that more than $80 \%$ of the net ACC transport at $0^{\circ} \mathrm{E}$ is accounted for by the three inner fronts, with $42 \%, 28 \%$, and $13 \%$ for the SAF, PF, and SACCF, respectively. The individual front transports in the $0^{\circ} \mathrm{E} C \mathrm{CD}$ and XBT transects revealed several cases of opposite variations of the PF and SACCF transports, an indication that a local bathymetric feature culminating at less than $1500 \mathrm{~m}$ around $51^{\circ} \mathrm{S}-4^{\circ} \mathrm{E}$ (the Shona Ridge) cause occasional volume transfers between the two fronts. A bathymetric influence on the SACCF is certainly favored by the proximity of this front to the crest of the Mid-Atlantic 
ridge at this longitude, as reflected by the very weak contribution (1.4 Sv) of the layer below $2500 \mathrm{~m}$ to this front transport in Table 4.

\begin{tabular}{|c|c|c|c|c|c|}
\hline & STF & SAF & $\mathrm{PF}$ & SACCF & SBdy \\
\hline CTD- $0^{\circ} \mathrm{E}: \mathrm{Tr}_{\text {bottom }}(\mathrm{Sv})$ & $10.7(7 \%)$ & $61.1(42 \%)$ & $40.6(28 \%)$ & $19.1(13 \%)$ & $15.5(11 \%)$ \\
\hline $\operatorname{Tr}_{2500}(\mathrm{~Sv})$ & $3.9 \quad(4 \%)$ & $31.6(36 \%)$ & $29 \quad(33 \%)$ & $17.7(20 \%)$ & $7.3 \quad(8 \%)$ \\
\hline $\operatorname{Tr}_{2500}(\mathrm{~Sv})$ & $9.9 \pm 8(10 \%)$ & $28.3 \pm 8(29 \%)$ & $31.4 \pm 12(32 \%)$ & $20.3 \pm 10(21 \%)$ & $5.1 \pm 3(5 \%)$ \\
\hline CTD-30 ${ }^{\circ} \mathrm{E}: \operatorname{Tr}_{\text {bottom }}(\mathrm{Sv})$ & $7.8(5 \%)$ & $47.6(32 \%)$ & $99.3(68 \%)$ & $32.5(22 \%)$ & $13.4(9 \%)$ \\
\hline $\operatorname{Tr}_{2500}$ (Sv) & $2.2(3 \%)$ & $27.3(31 \%)$ & $50.3(57 \%)$ & $15.6(25 \%)$ & $5.2(6 \%)$ \\
\hline
\end{tabular}

Table 4: Baroclinic transports of each ACC front and percentage contributions to the total net transports.

\section{ACC transport variations in the Atlantic sector:}

Associating the ACC transports of Table 3 at $0^{\circ} \mathrm{E}$ and $30^{\circ} \mathrm{E}$ with previous estimates in the Drake Passage (137 $\pm 8 \mathrm{~Sv}$; Cunningham et al., 2003), at $35^{\circ} \mathrm{W}$ (157 Sv; Heywood and King, 2002), and at $33^{\circ} \mathrm{E}$ (159 Sv; Read and Pollard, 1993) provides us with a regular sampling along the Atlantic sector. Although the above values at $35^{\circ} \mathrm{W}$ and $33^{\circ} \mathrm{E}$ were adapted to our ACC transport definition (with half the STF and Sbdy transports included), the uncertainties, time variations, and a possible barotropic contribution should be kept in mind when discussing the longitudinal variations of the baroclinic transports. From the water mass transport breakdown proposed by Heywood and King (2002), the $20 \mathrm{~Sv}$ excess at $35^{\circ} \mathrm{W}$ relative to Drake Passage should be mostly ascribed to an injection of North Atlantic Deep Water (NADW) in the SAF in the western boundary region. On the basis of isopycnal salinity distributions at deep levels (Arhan et al., 2003), we suggest that the decrease from $157 \mathrm{~Sv}$ at $35^{\circ} \mathrm{W}$ to $145 \mathrm{~Sv}$ at $0^{\circ} \mathrm{E}$ (Table 3) reflects a northward loss of Circumpolar Deep Water (CDW) by the ACC. If correct, this would be a partial compensation to the gain of NADW to the west of $35^{\circ} \mathrm{W}$, in the same depth range. The similarity of our $\mathrm{T}_{2500}$ value ( $\sim 90 \mathrm{~Sv}$ ) to the one obtained by Sokolov et al. (2004) in the Drake Passage is another indication that the net increase between the two longitudes takes place at the deep levels. Finally, our $154 \mathrm{~Sv}$ estimate at $30^{\circ} \mathrm{E}$ matches the $159 \mathrm{~Sv}$ value at $33^{\circ} \mathrm{E}$, and the water mass analysis of read and Pollard (1993) suggests that southward transfer of water across the STF south of the Agulhas retroflection might explain the increase from $0^{\circ} \mathrm{E}$ to $30^{\circ} \mathrm{E}$.

\section{Acknowledgements:}

We are grateful to Dr A. Orsi for providing numerized files of the ACC fronts. JFL thanks Pr. J. Lutjeharms for a 3-month stay in the Oceanography Department of the University of Cape 
Town. SSp and MA acknowledge support from IFREMER and INSU/CNRS through the French Programme National d'Etude de la Dynamique du Climat (PNEDC).

\section{References:}

Arhan M., H. Mercier and Y.-H. Park, On the deep water circulation of the eastern South Atlantic Ocean, Deep-Sea Res. I, 50, 889-916, 2003.

Cunningham S.A., S.G. Alderson, B.A. King and M.A. Brandon, Transport and variability of the Antarctic circumpolar Current in drake Passage, J. Geophys. Res., 108, C5, 8084, doi:10.1029/2001JC001147, 2003.

Gordon A.L., R.F. Weiss, W.M. Smethie, Jr., and M. Warner, Thermocline and intermediate water communication between the South Atlantic and Indian oceans, J. Geophys. Res., 97, 7223-7240, 1992.

Heywood K.J. and B.A. King, Water masses and baroclinic transports in the South Atlantic a,d Southern Oceans, J. Mar. Res., 60, 639-676, 2002.

Lemke P., 1994, The Expedition ANTARKTIS X/4 of the Research Vessel "Polarstern" in 1992. Ber. Polarforsch., 140, 90pp.

Orsi A.H., T. Whitworth III and W.D. Nowlin, On the meridional extent and fronts of the Antarctic Circumpolar Current, Deep-Sea Res. I, 42, 641-673, 1995.

Read J.F. and R.T. Pollard, Structure and transport of the Antarctic Circumpolar Current and Agulhas return Current at 40E, J. Geophys. Res., 98, 12281-12295, 1993.

Rintoul S.R., S. Sokolov and J. Church, A 6 year record of baroclinic transport variability of the Antarctic Circumpolar Current at $140^{\circ} \mathrm{E}$ derived from expendable bathythermograph and altimeter measurements, J. Geophysical Res., 107, 3155, doi:10.1029/2001JC000787, 2002.

Roether W., M. Samthein, T.J. Müller, W. Nellen and D. Sahrhage, SüdatlantikZircumpolarstrom, Reise Nr 11, 3 Oktober 1989-11 März 1990, Meteor-Ber. 90-2, Univ. Hamburg, Hamburg, Germany, 169 pp., 1990.

Smith W.H.F. and D.T. Sandwell, 1997, Global seafloor topography from satellite altimetry and ship depth soundings. Science, 277, 1956-1962.

Sokolov S., B.A. King, S.R. Rintoul, and R.L. Rojas, Upper ocean temperature and the baroclinic transport stream function relationship in Drake Passage, J. Geophys. Res., 109, C05001, doi:10.1029/2003JC002010, 2004.

Whitworth III T. and W.D. Nowlin, Jr., Water masses and currents of the Southern Ocean at the Greenwich Meridian, J. Geophys. Res., 92, C6, 6462-6476, 1987. 


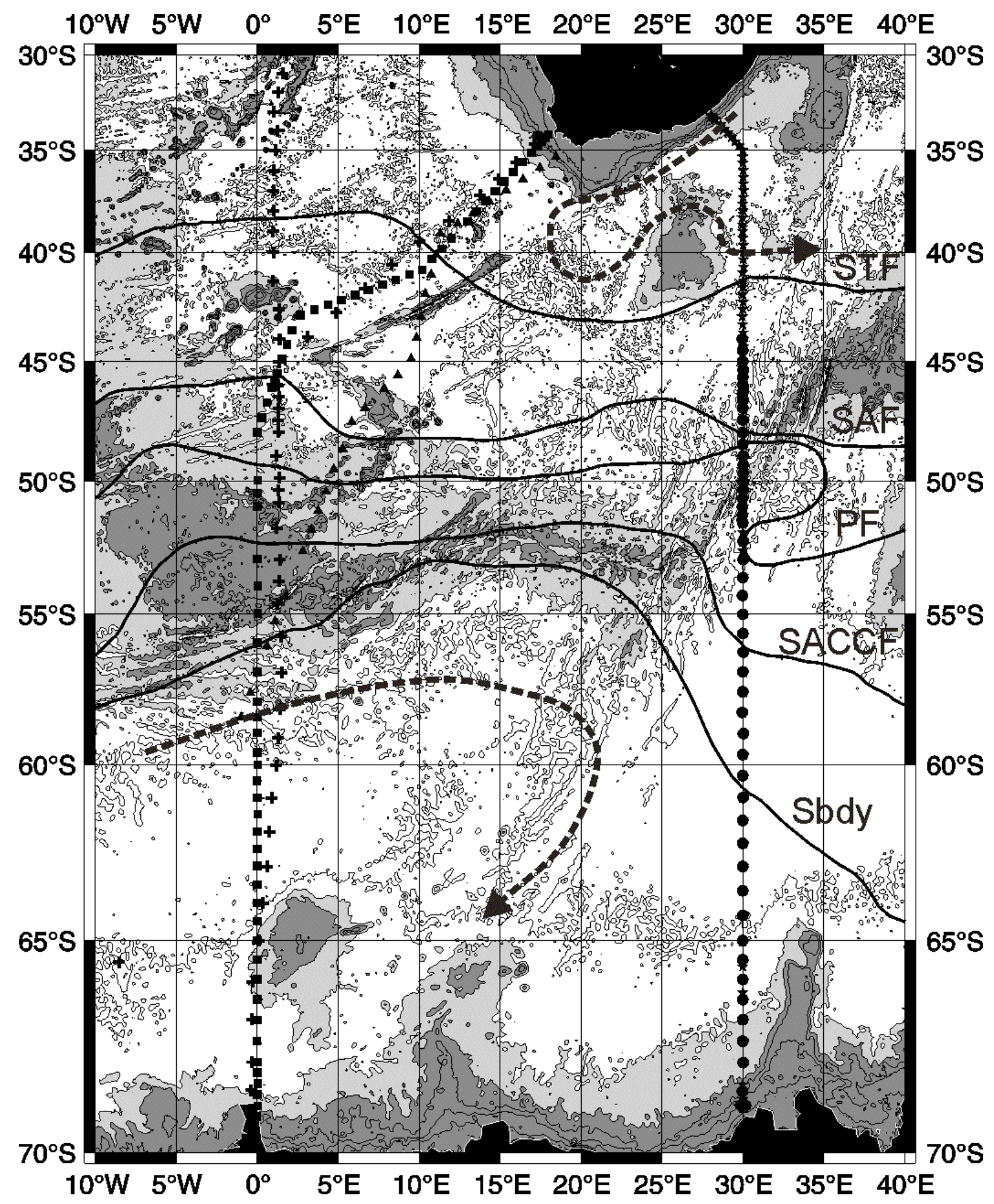

Figure 1: Tracks of the five CTD sections (see Table 1): AJAX (plus signs), A12 (squares), A21 (triangles), I6(stars), I6s (circles). Superimposed are the traces of the ACC fronts as given by Orsi et al. (1995), and schematics of the Weddell gyre and Agulhas Current circulations (only AJAX and A21 were in the data set used by Orsi et al., 1995). Isobaths 200 $\mathrm{m}$ and multiples of $1000 \mathrm{~m}$ are shown, with dark (light) shading between 0 and $3000 \mathrm{~m}$ (3000 $\mathrm{m}$ and $4000 \mathrm{~m}$ ) (Smith and Sandwell, 1997). 


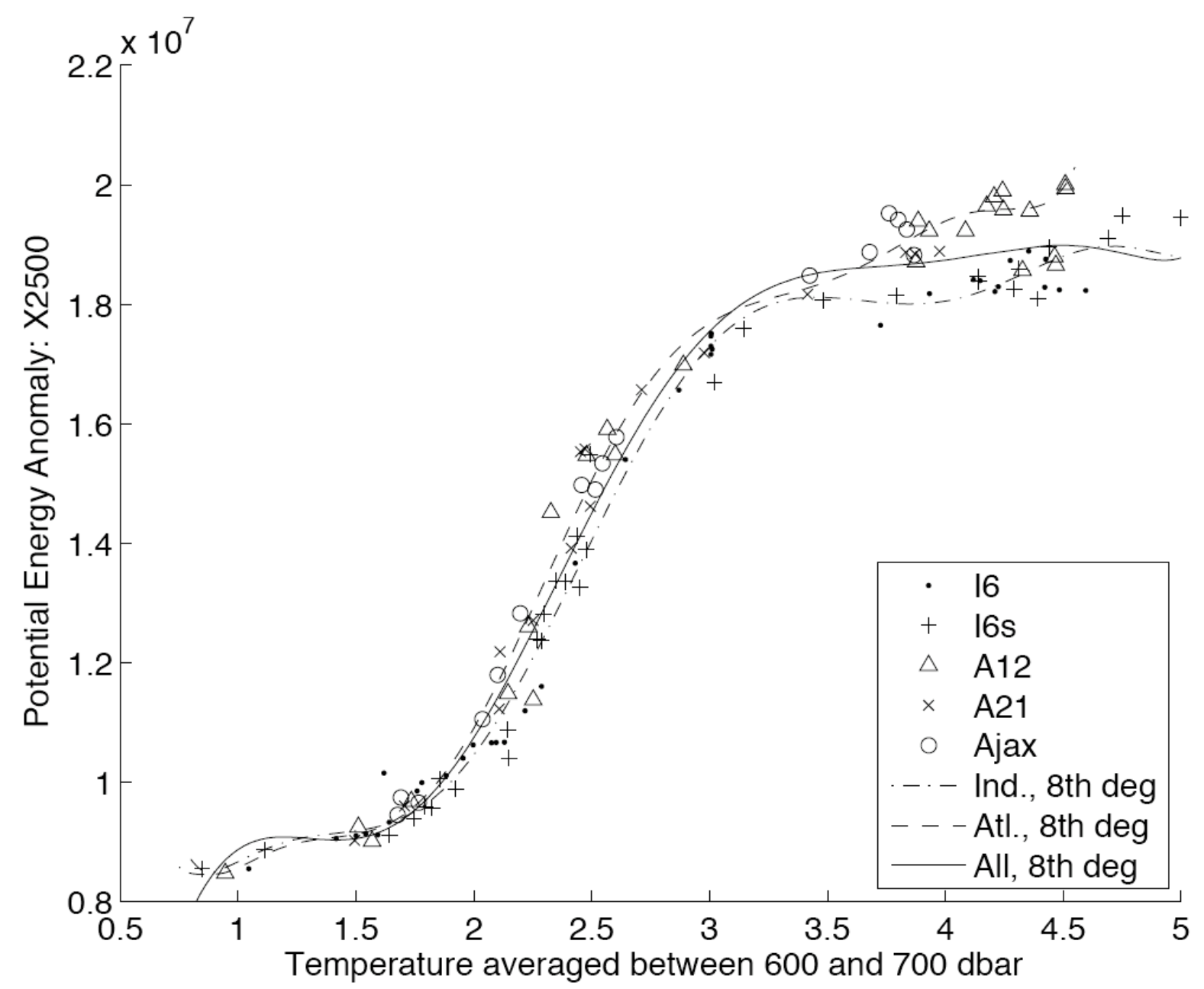

Figure 2: Potential energy anomaly integrated between 2500 dbar and the sea surface $\left(\chi_{2500}\right)$ versus temperature averaged between 600 and $700 \mathrm{dbar}\left(\mathrm{T}_{650}\right)$. The curves are $8^{\text {th }}$ degree polynomials fitted to the stations at $0^{\circ} \mathrm{E}$ nominal, $30^{\circ} \mathrm{E}$, and the totality. 


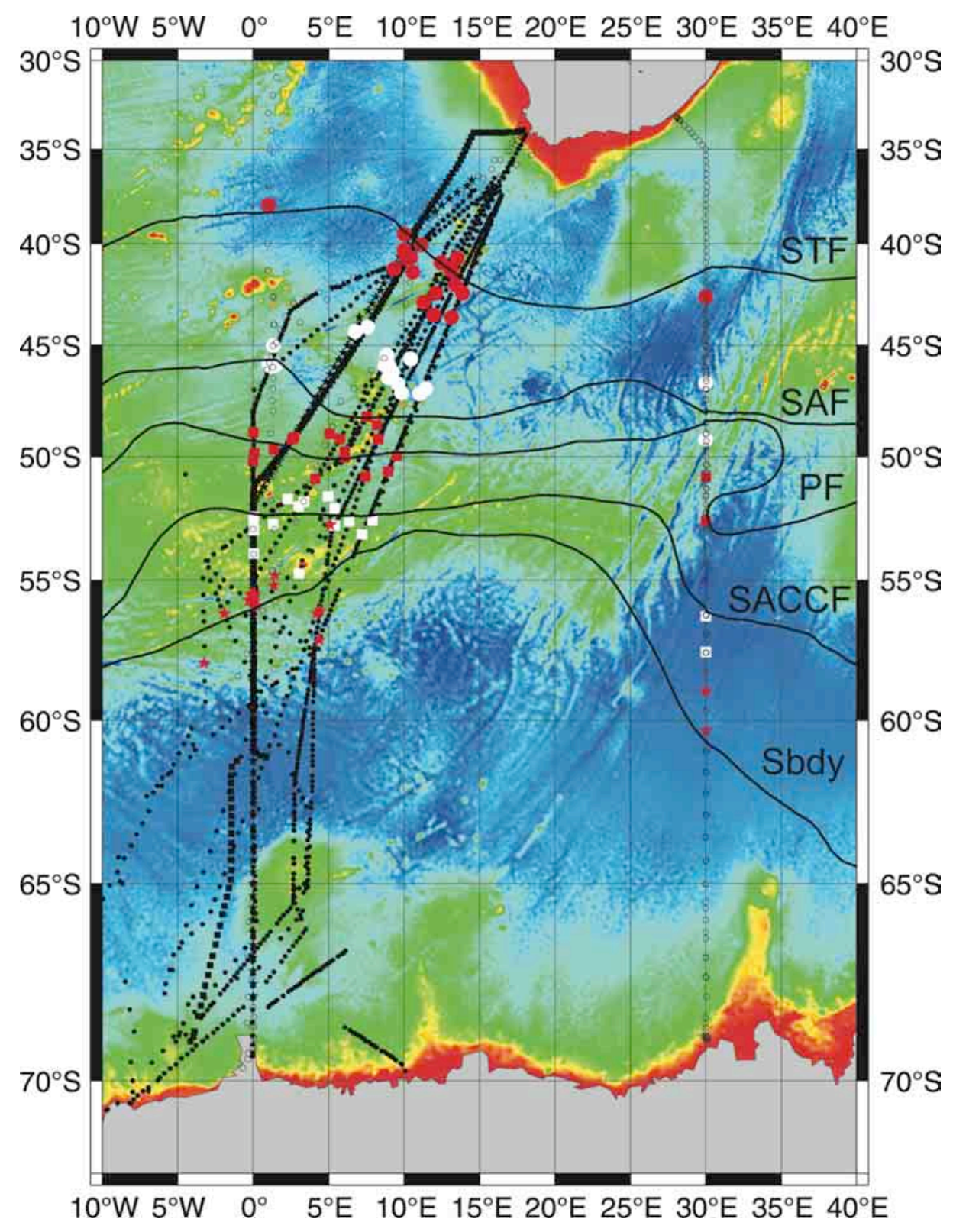

Figure 3: XBT sections used to estimate the ACC baroclinic transports (black symbols): GoodHope section (square), AARI section (star), AWI sections (dots). The CTD lines of Figure 1 are also displayed (open circles). ACC boundaries and fronts are shown for each section (STF: red circles; SAF: white circles; PF: red squares; SACCF: white squares; SBdy: red stars) and their traces from Orsi et al. (1995). 

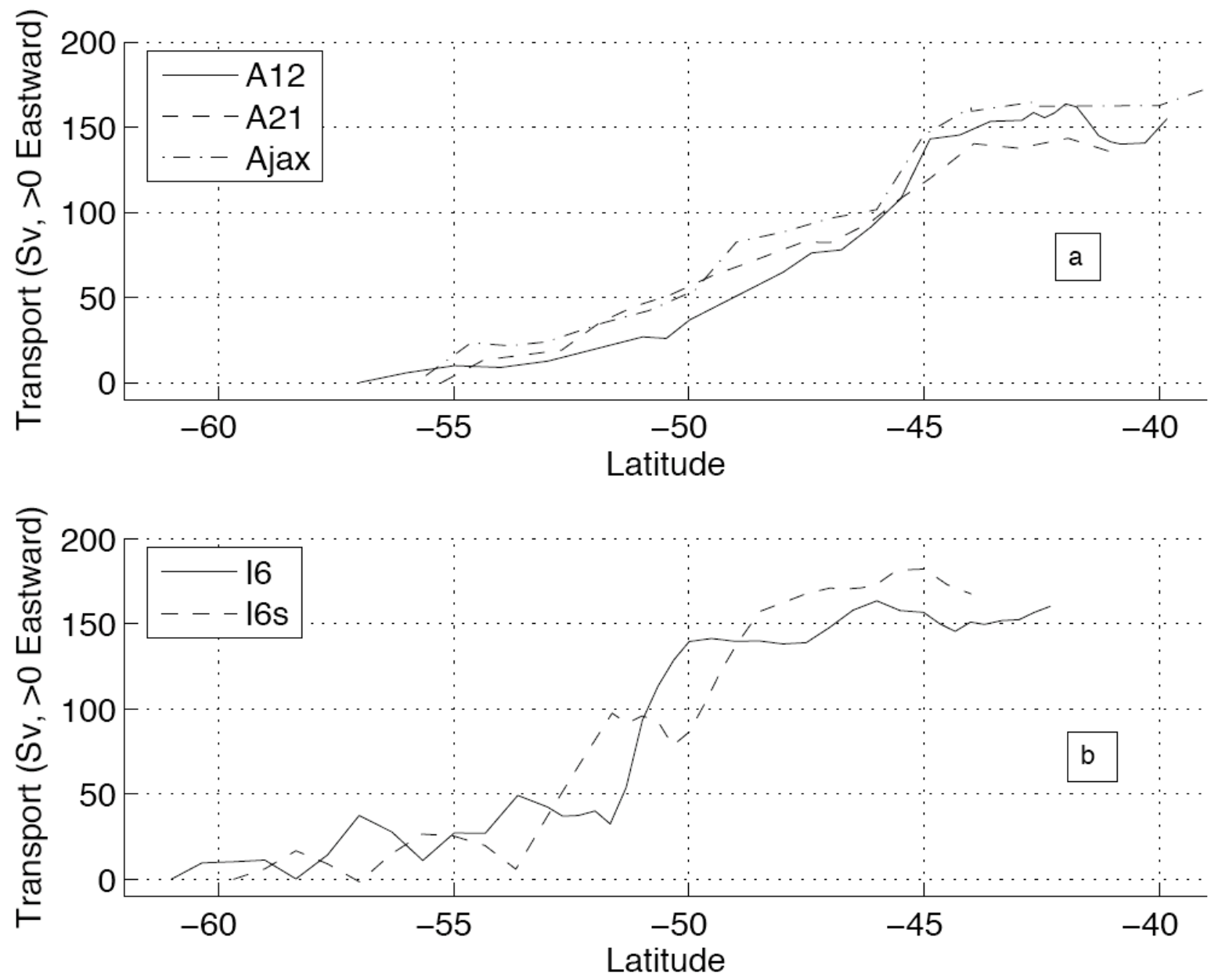

Figure 4: Northward accumulated geostrophic full-depth transports (bottom-referenced) at $0^{\circ} \mathrm{E}$ nominal (a) and $30^{\circ} \mathrm{E}(\mathrm{b})$. 